ISSN 1693-3079

\title{
TOKSIN BOTULINUM (Kajian Pustaka)
}

\author{
Elin Hertiana \\ Staf Pengajar Prostodonsia FKG UPDM(B) Jakarta
}

\begin{abstract}
ABSTRAK
Toksin botulinum adalah suatu neurotoxin yang diproduksi oleh bakteri Clostridium botulinum yang dapat menyebabkan paralisis sementara pada otot jika diinjeksikan di sekitarnya. Ada tujuh strain botulinum, yaitu A, B, C, D, E, F, dan G. Botulinum tipe A (BTX-A) dan tipe B (BTX-B) yang banyak digunakan untuk pengobatan. Toksin botulinum bekerja dengan cara menghambat pelepasan asetilkolin sehingga otot tidak dapat berkontraksi dan terjadi paralisis sementara. Penyembuhan parsial akan terjadi dalam 28 hari dan dalam waktu 3- 6 bulan otot akan berkontraksi kembali.
\end{abstract}

Kata kunci: toksin botulinum, otot, paralisis.

\section{ABSTRACT}

Botulinum toxin is a neurotoxin produced by bacterium Clostridium botulinum that can cause temporary paralysis of the muscles. There are seven botulinum strains: A, B, C, D, E, F, and G. Botulinum type A(BTX-A) and type B (BTX-B) are widely used for treatment. Botulinum toxin works by inhibiting the release of neurotransmitter acetylcholine so the muscle unable to contract and cause temporary paralysis. Partial healing will occur within 28 days and within $3-6$ months the muscle will contract again.

Key words: botulinum toxin, muscle, paralysis.

\section{PENDAHULUAN}

$\mathrm{T}$ oksin botulinum adalah suatu neurotoxin yang diproduksi oleh bakteri Clostridium botulinum yang dapat menyebabkan paralisis sementara pada otot jika diinjeksikan di sekitarnya. Pada awalnya toksin botulinum dipakai untuk pengobatan gangguan pergerakan bola mata, seperti strabismus dan blepharospasm. Toksin ini kemudian berkembang untuk digunakan dalam bidang dermatologis dan neurologis. Saat ini toksin botulinum telah banyak dipakai untuk pengobatan dalam bidang kedokteran gigi.

\section{KAJIAN PUSTAKA}

\section{Sejarah}

Toksin botulinum diproduksi oleh bakteri Clostridium botulinum, yaitu bakteri anaerob, gram positif, membentuk spora, dan berbentuk batang. Pada tahun 1820 seorang Dokter dan penyair Jerman, Justinus Kerner menamakan toksin botulinum sebagai "Sausage poison” (racun sosis), karena bakteri ini menyebabkan keracunan akibat tumbuh di olahan daging yang penanganannya tidak baik. Beliau adalah orang pertama yang mengemukakan ide penggunaan toksin ini untuk pengobatan. Tahun 1895, Emile Van Ermengem pertama kali mengisolasi bakteri Clostridium botulinum, tahun 1944 Edward Schantz membiakkan Clostridium botulinum dan mengisolasi toksinnya. Baru pada tahun
1949 Burgen dkk. menemukan bahwa toksin ini dapat menghambat transmisi saraf otot. Pada tahun 1950, Alan Scott seorang opthalmologist menggunakan toksin ini dalam beberapa percobaan klinis. Hasilnya diketahui bahwa toksin botulinum dapat digunakan untuk pengobatan strabismus dan blepharospasm. Penggunaan toksin botulinum kemudian berkembang untuk pengobatan dalam bidang dermatologis dan neurologis. Pada tahun 1989 melalui serangkaian percobaan klinis dan laboratorium, Food and Drug Administration (FDA) atau badan pangan dan obatobatan Amerika menyetujui penggunaan botulinum toksin untuk pengobatan strabismus, blepharospasm, dan hemifacial spasm pada pasien berusia diatas 12 tahun. ${ }^{1,2}$

\section{Tipe Botulinum}

Terdapat tujuh strain botulinum, masingmasing memproduksi protein yang berpotensi sebagai neurotoxin. Strain tersebut adalah A, B, C, D, E, F, dan $G$ dengan berbagai potensi, spesifisitas spesies, dan reseptor target. Botulinum tipe A (BTX-A) dan tipe B (BTX-B) secara antigen berbeda, tetapi memiliki fungsi yang sama dan banyak digunakan untuk pengobatan. Berikut ini adalah beberapa merk dagang untuk toksin botulinum: ${ }^{2,3}$

Toksin botulinum tipe A : Botox ${ }^{\circledR}$ (Allergan, Irvine, CA), 
Dysport $^{\circledR}$ (Speywood Pharmaceuticals, Maidenhead, UK), Xeomin ${ }^{\circledR}$ (Merz Pharmaceuticals, Germany), Prosigne $^{\circledR}$ (Lanzhou Biological Products Institute, China).

Toksin botulinum tipe B : Myobloc $^{\circledR}$ (Elan Pharmaceuticals, San Diego, CA), dan Neurobloc ${ }^{\circledR}$ (Elan Pharmaceuticals, Shannon, County Clare, Ireland).

\section{Sediaan dan dosis}

Toksin botulinum disimpan dalam vial beku (2$4^{\circ} \mathrm{C}$ ) dengan dosis $100 \mathrm{U}$ atau $500 \mathrm{U}$. Ketika akan digunakan, maka sediaan yang berbentuk kristal putih ini harus ditambahkan larutan saline $0,9 \%$ dan harus digunakan dalam waktu 4 jam. Toksin umumnya diinjeksikan menggunakan tuberculin syringe $1,0 \mathrm{ml}$ dengan jarum berukuran $26-30 .^{4}$

Total dosis maksimal per kunjungan untuk toksin botulinum tipe A tidak boleh melebihi dari 300 - $400 \mathrm{U}$, dan interval diantaranya tidak boleh kurang dari 3 bulan. Apabila volume dan dosis dari toksin botulinum yang diinjeksikan terlalu besar, maka toksin ini dapat berdifusi ke otot yang bersebelahan dan menyebabkan otot tersebut juga mengalami paralisis. ${ }^{5}$

\section{Indikasi toksin botulinum dalam kedokteran gigi}

Di bidang kedokteran gigi, toksin botulinum digunakan dalam pengobatan gangguan sendi temporomandibula, sakit kepala, trigeminal neuralgia, migrain, myofacial pain, gummy smile, asymmetrical smile, hipertropi otot masseter dan temporalis, mandibular spasm (trismus), prosedur bedah dan hemifacial spasm serta sialorrhea. ${ }^{2}$ Keberhasilan penggunaan botulinum toksin dalam kedokteran gigi terutama untuk pengobatan myofacial pain masih menjadi pro dan kontra. Climent dkk. pada tahun 2012 melakukan analisa kualitatif terhadap penggunaan botulinum toksin dalam pengobatan myofascial pain dengan cara mengumpulkan 19 percobaan klinis dan 15 systematic review yang diambil dari PubMed. Mereka mengalami kesulitan untuk mengambil kesimpulan. Hal ini disebabkan oleh berbagai faktor, diantaranya berbagai percobaan menggunakan kriteria diagnosis yang berbeda untuk myofascial pain, otot yang diinjeksi tidak sama atau bahkan tidak disebutkan, prosedur injeksi, jumlah trigger point yang diinjeksi serta dosis yang bervariasi, grup kontrol yang berbeda-beda, serta hasil yang juga bervariasi. Pada akhirnya mereka mengambil tiga kesimpulan, yaitu toksin botulinum tidak direkomendasikan, tidak direkomendasikan tetapi juga tidak ditolak, serta direkomendasikan hanya untuk rasa sakit spesifik atau sulit diobati atau untuk rasa sakit dengan diagnosis topografi spesifik. ${ }^{6}$

\section{Kontra Indikasi dan Efek samping}

Terdapat beberapa kontra indikasi relatif seperti kehamilan, menyusui, penyakit neuromuscular (myasthenia gravis, Eton-Lambert syndrome, multiple sclerosis), motor-neuron diseases, sensitifitas terhadap toksin, interaksi obat dengan amino glycosides, antibiotik, quinidine, calcium channel blockers, magnesium sulfate, succinylcholine, dan polymyxin. Efek samping toksin botulinum pada pengobatan gangguan oromandibula meliputi facial nerve palsy, rasa sakit pada daerah injeksi, gejala seperti flu, kelemahan pada otot disekitarnya, dysphagia, dan hematoma. Efek ini umumnya hanya bersifat sementara dan akan pulih kembali dalam beberapa minggu. ${ }^{2,7}$

\section{PEMBAHASAN}

Mekanisme Toksin Botulinum $^{8,9}$

Toksin botulinum bekerja dengan cara menghambat pelepasan asetilkolin pada neuromuscular junction. Asetilkolin adalah neurotransmiter dalam sistem saraf otonom yang berfungsi untuk merangsang kontraksi otot. Asetilkolin secara normal menyebar melintasi celah sinapsis pada neuromuscular junction ke reseptor pengikat asetilkolin pada motor end plate di sel otot. Pengikatan asetilkolin pada reseptor tersebut memicu peningkatan dalam pembukaan kanal ion sodium dan potasium. Hal ini akan menyebabkan depolarisasi motor end plate dan terjadi kontraksi otot.

Pada saat toksin botulinum diinjeksikan ke dalam otot, maka toksin akan berikatan dengan cholinergic nerve terminal, lalu terjadi endositosis dalam sitoplasma dari syaraf. Ikatan ini akan membentuk suatu kompleks dengan neuronal protein dan menyebabkan proteolisis SNAP 25 - sebuah synaptosomal associated protein yang membantu penyatuan vesikel synaptic dengan membran terminal saraf. Hal ini akan berakibat pada penurunan frekuensi asetilkolin yang dilepaskan pada celah sinaptik dan menghambat terjadinya exocytosis. Motor end plate akan kehilangan reseptor asetilkolin sehingga tidak ada aktivitas saraf pada target organ dan hilangnya suplai saraf pada otot.

Neurotoxin ini mengganggu proses kontraksi otot skeletal dan menyebabkan paralisis sementara. Dalam waktu 4 hari, terjadi pertumbuhan collateral terminal untuk mencoba ber-reinnervasi dengan neuromuscular junction. Penyembuhan parsial akan terjadi dalam 28 hari. Dua bulan setelah injeksi, terminal syaraf akan mampu melepaskan asetilkolin dan endplate connection akan pulih, sekitar 3-6 bulan otot akan berkontraksi kembali. Itu sebabnya pengobatan dengan toksin botulinum membutuhkan injeksi ulang setelah beberapa waktu. Mekanisme toksin ini dapat dilihat pada gambar 1.
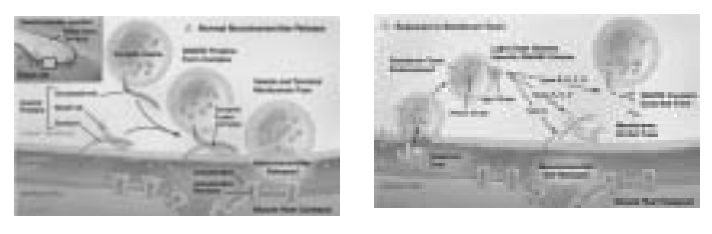

GAMBAR 1.

Mekanisme toksin botulinum. ${ }^{8}$ 


\section{Teknik injeksi toksin botulinum}

Pada gangguan sendi temporomandibula, otot yang sering terkena adalah otot temporalis, otot masseter dan otot pterygoid lateral. Otot temporalis dan otot masseter biasanya selalu terlibat dan merupakan sumber rasa sakit langsung. Keterlibatan otot pterygoid lateral biasanya berhubungan dengan rasa sakit di daerah bukal, deviasi rahang atau bruxism. Injeksi pada otot dapat berguna untuk mengurangi rasa sakit. Pada myofascial pain pasien merasakan ototnya tegang dan terasa sakit ketika diraba. Hal ini disebut sebagai trigger point dan kadang berperan dalam memproduksi penyebaran rasa sakit. Ketika hal ini terjadi, trigger point dapat diinjeksi dan penyebaran rasa sakit akan berhenti..$^{7,10}$

Untuk melakukan injeksi trigger point, pertama-tama tentukan lokasi trigger point dengan melakukan palpasi pada otot dengan tekanan yang ringan (Gambar 2.A). Ketika lokasi trigger point telah ditentukan, lakukan palpasi di sekitarnya sampai teraba daerah yang paling sakit (perhatikan ekspresi pasien). Bersihkan daerah tersebut dengan alkohol, lalu tahan dengan dua jari agar tidak bergerak saat injeksi dilakukan (Gambar 2.B). Masukkan jarum ke dalam daerah tersebut. Keakuratan lokasi injeksi dapat diperoleh dari feedback pasien. Setelah mendapatkan kedalaman yang tepat, lakukan aspirasi lalu injeksikan larutan anestesi ke dalamnya (Gambar 2.C). Tarik jarum sedikit dan ubah arah jarum $10-15$ derajat dan masukkan kembali jarum dengan kedalaman yang sama. Lakukan aspirasi lalu injeksi. Ulangi pada beberapa daerah di sekitar trigger point (Gambar 2.D). Setelah selesai, tarik seluruh jarum dan tekan daerah injeksi dengan kasa steril selama 10 - 20 detik untuk mendapatkan hemostasis yang baik (Gambar 2.E). ${ }^{10}$
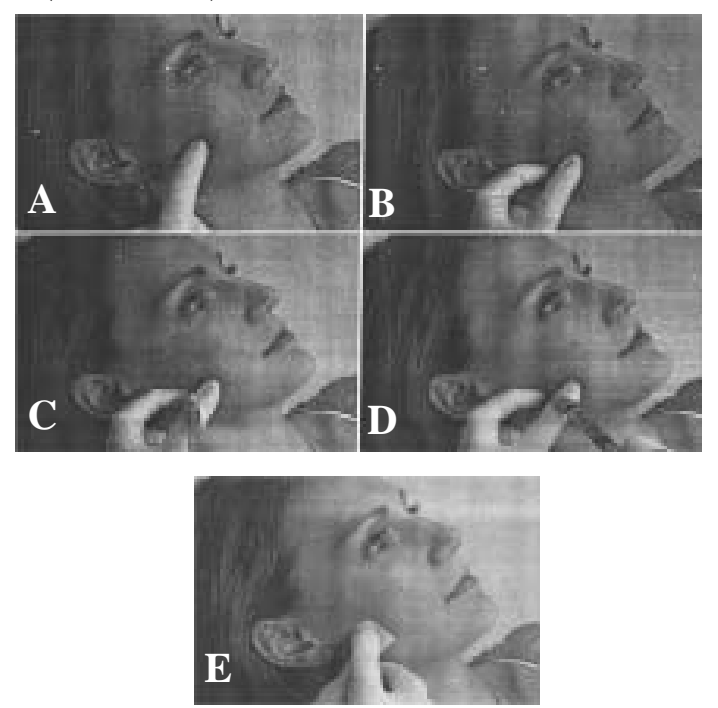

GAMBAR 2.

Teknik injeksi toksin botulinum. ${ }^{10}$

Teknik diatas adalah teknik yang digunakan secara umum untuk injeksi otot; bagaimanapun variasi unik dari masing-masing otot dapat memberikan perbedaan. Penting bagi seorang dokter untuk mengetahui anatomi dari otot yang akan diinjeksi untuk menghindari kerusakan pada jaringan sekitar. Toksin botulinum yang digunakan dalam pengobatan gangguan sendi temporomandibula biasanya memiliki konsentrasi $2,5-5,0$ units per $0,1 \mathrm{ml}$ dengan dosis awal $10-25$ units untuk tiap otot temporalis, 25 - 50 unit untuk otot masseter dan 7,5 - 10 units untuk otot pterygoid lateral. Dosis tersebut bersifat individual dan berdasarkan respon dari pasien. Toksin botulinum berdifusi $1 \mathrm{~cm}$ disekitar daerah injeksi. Untuk menghindari respon yang tidak sempurna, sebaiknya digunakan dosis dengan konsentrasi rendah pada berbagai area dengan volume injeksi yang banyak. ${ }^{7,10}$

\section{RINGKASAN}

Toksin botulinum adalah toksin yang diproduksi oleh bakteri Clostridium botulinum. Toksin botulinum bekerja dengan cara menghambat pelepasan asetilkolin sehingga otot tidak dapat berkontraksi dan terjadi paralisis sementara. Toksin botulinum pada beberapa penelitian terbukti dapat digunakan dalam pengobatan di bidang kedokteran gigi. Tidak adanya efek samping yang berbahaya membuat toksin ini dapat menjadi alternatif pengobatan penyakit yang berhubungan dengan otot dan saraf, terutama yang tidak dapat disembuhkan dengan pengobatan konvensional.

\section{DAFTAR PUSTAKA}

1. Kharistya. Mekanisme Botulinum Toxin. [cited 20 Desember 2016]; Available from URL: http:// kharistya.wordpress.com/2006/06/24/mekanismebotulinum-toksin.

2. Filho RR, Zimmermann GS, Gonçalves BM. Applications of Botulinum Toxin in Dentistry - Literature Review. $J$ Dent Oral Biol. 2016; 1(3): 1013.

3. Govindaraju P, Sadand S, Venugopal S, et al. Botulinum toxin-An Innovative Treatment Approach in Dental Practice. J Young Pharm. 2016; 8(1): 2-5.

4. Srivastava S, Kharbanda S, Pal US, et al. Applications of botulinum toxin in dentistry: A comprehensive review. Natl J Maxillofac Surg 2015 Jul-Dec;6(2):152-9.

5. Royal MA. Botulinum Toxin in Pain Management. Phys Med Rehabil Clin N Am 2003;14:805-20.

6. Climent JM, Kuan TS, Fenollosa P, Martin-del-Rosario P. Botulinum Toxin for the Treatment of Myofascial Pain Syndromes Involving the Neck and Back: A Review from a Clinical Perspective. Evidence-Based Complementary and Alternative Medicine Volume 2013 (2013), Article ID 381459.

7. Mor N, Tang C, Blitzer A. Review : Temporomandibular Myofacial Pain Treated with Botulinum Toxin Injection. Toxins 2015;7: 2791-800.

8. Arnon SS, Schechter R, Inglesby TV, et al. Botulinum Toxin as a Biological Weapon Medical and Public Health Management. JAMA. 2001;285:1059-70.

9. Ko GD, Finkelstein I, Freund B, Dhawan P. Botulinum Toxin Type A in Pain Management. Practical Pain Management. October 2008. p.18-30.

10. Okeson JP. Management of Temporomandibular Disorders and Occlusion. $6^{\text {th }}$ ed. Amerika : Elsevier Mosby.2008.p.291,383-4. 